\title{
Environmental Advocacy Dilemma on Tin Mining Communities in Bangka Belitung
}

\author{
Ibrahim Ibrahim $^{1 *}$, Dwi Haryadi ${ }^{2}$, and Nanang Wahyudin ${ }^{3}$ \\ ${ }^{1}$ Department of Political Science, Faculty of Social and Political Sciences, Universitas Bangka Belitung, Bangka - Indonesia \\ ${ }^{2}$ Department of Law, Faculty of Law, Universitas Bangka Belitung, Bangka - Indonesia \\ ${ }^{3}$ Department of of Management, Faculty of Economic, Universitas Bangka Belitung, Bangka - Indonesia
}

\begin{abstract}
Tin mining generally results in massive environmental damage. This condition occurs in Bangka Belitung as an area rich in tin natural resources. Due to the environmental damage, tin mining in this area runs along with several rejection of the mine. Environmental activists will generally assist the community in carrying out resistance movements. However, environmental activists will face various dilemmas in advocacy. This paper discusses how the environmental advocacy dilemma in the tin mining community in Bangka Belitung. The study model used is a qualitative model by collecting data in the form of in-depth interviews and conservation. This study found four important things, namely: first, the tendency of society to split in two different attitudes in the context of tin mining. The gap focused on at least 10 dimensions of attitude difference. Second, the study found that the environmental advocacy movement generally centered on the aspect of rejecting the existence of tin mines in the sea and coastal areas as well as Watersheds (DAS). Third, environmental activists are always faced with intimidation and pressure from paid groups by investors. Environmental activists generally face back pressure from counter-pressure groups. Fourth, this study also found that people tended to be apathetic towards the environmental advocacy movement, some of them because they were worried about pressure and partly because they felt unaffected or directly related. The study also found that apathy also arises because of the pragmatism of the people in certain regions which are actually accommodating to tin mining.
\end{abstract}

\section{Introduction}

As a tin mining area which is the main producer of tin in Indonesia and at the same time making Indonesia the second largest tin producer in the world after China [1, 2, $3,4]$, Bangka Belitung is an area whose main income is generally based on tin mining. Although holding the position as the second most engaged profession $[5,6]$, the tin mine is very familiar with the people in this area. It can be said that since tin was allowed to be mined by elements outside the official company recognized by the state in 1998 , tin was practically the excellent in this area $[7,8,9$, 10]. The implication is that chaotic management and environmental damage cannot be easily resolved $[11,12$, 13, 14, 15], even by the government.

At the same time, tin mining has divided communities in this area into two main poles, namely those who agree with tin mining and those who refuse. However, there is a variety of mining that must be understood, namely that tin mining is dynamically divided between those who reject and accept, between those directly and indirectly affected, between large companies and small companies, between authorized licensed mining and unlicensed companies, and between mining actors and environmentalists. This study limits tin mining in a broad context, which concerns all problems that can run on all dimensions and levels.
In the midst of such dynamic conditions as mentioned above, efforts to save the environment emerged haltingly in the midst of a divided mining community. Efforts to provide assistance and struggle against the ecological dimension do not only concern those who struggle to defend it, but also for what purpose. In fact, that these days the Bangka Belitung region faces a real threat in the form of environmental damage and an increasingly widespread land crisis. The area of damage extends from land and reaches the sea and coastal areas. The conflict becomes unavoidable, but on the other hand the business to carry out mining continues. Several studies have illustrated how the tin mining conflict runs, but on the other hand resistance also continues. In the midst of these conditions, advocacy is a key word. There are not many institutions and activists who are advocating for tin mines amid the cleavage of mining communities in this area.

Advocacy becomes important thing as a way to assist the community in fighting against environmental crime. In the midst of high community apathy, the author departs from the basic assumption that advocacy in the mining community is not easy to do. This study discusses the fundamental challenges of environmental advocacy in the tin mining community in Bangka Belitung.

\footnotetext{
* Corresponding author: iim_babel@yahoo.com
} 


\section{Research Methodology}

This paper is processed from the results of qualitative research. The focus of this paper is the environmental advocacy dilemma of the tin mining community so that the data needed is data relating to the challenges of environmental advocacy obtained from environmental activists who are persistent in providing assistance to the community or communities around the mine area. The informants are determined based on the principle of purposive sampling, namely the determination of informants based on certain considerations, namely the belief that the informant has the information needed. The informants in this matter were environmental activists, either institutionally engaged in the name of nongovernmental organizations or individually active in advocacy. The data collection technique in this study was in-depth Focus on cleavage and dimensions of disparity

\section{Finding and Discussion 2.1 Split Society}

Since the status of tin was revoked as a strategic commodity of the country, practically tin was not fully regulated by the state (central government). This condition has been going on since 1998 when the central government revoked the status of tin commodities and provided opportunities for people and entrepreneurs outside the country who were authorized by the state through two large companies, namely PT. Timah and PT. Kobatin. Since then tin has been used as a free commodity mined by various local groups. The central government does consider tin not strategic because it is only needed by a small number of manufacturing industries, but its existence is irreplaceable. However, the placement of tin as a commodity not a strategic state has had very broad implications.

People in Bangka Belitung is divided into several poles of interest. The poles of interest intersect with various patterns that tend to cross each other. But in general the author identifies several societal cleavages.

First, the community is divided between those who approve massive tin mining and those who refuse tin mining. In general, those who agree are usually people who have a direct interest in tin extraction in this area, while those who refuse are generally concerned about the environmental damage caused.

Second, the community is divided between those who support the existence of unconventional mines (TI) that are cultivated by ordinary people and those who refuse because they assume that tin mining is not environmentally friendly.

Third, the community is divided between those who support offshore mining and those who refuse. The context of his attitude is determined by his connection with life on the coast.

Fourth, the community is divided between those who agree that tin mining is carried out by large companies only and those who agree that tin mining is carried out by anyone.
Fifth, the community is divided between activist groups that encourage open tin mining and activists who reject tin mining conducted in ways that are not legal and not friendly to the environment..

Sixth, the entrepreneurs themselves are divided between those who support and cooperate with the largest tin companies in this area, namely PT. Timah, Tbk, and those who did not establish cooperation and hoped that the interests of tin companies outside of PT. Timah, tbk, also considered its business interests.

Seventh, the government itself is divided between the interests of the regional government and the central government which are often different, especially in the distribution of tin profits and the impact of environmental damage caused by mining.

Eighth, the community itself is determined by its direct relationship with tin mining and those who do not. Some people feel that there is no problem with the existence of a massive tin mine because it is indeed not part of tin mining and those who are directly related to tin mining. In the end, this interest divided the attitude of the community between those who cared and did not feel disturbed by the issue of tin mining.

Ninth, there are differences in attitudes that are constructed concerning the implications of tin mining on the environment. Most assume that tin mining is not too damaging to the environment, some consider that tin mining is very destructive to the environment.

In the end, tenth, there was a difference in attitude in looking at the tin mining extraction process. Some want only tin to be mined and enjoyed as a gift of natural wealth, and those who partially assume that to overcome the poor management of tin, the temporary cessation of the operation of the tin extraction process should be decided..

Based on the identification above, the cleavage of society in the context of tin extraction in Bangka Belitung is simplified in the following table form::

Table 1.Focus on Cleavage and dimensions of disparity

\begin{tabular}{|c|c|c|}
\hline No. & Focus on Cleavage & $\begin{array}{l}\text { Dimensions } \\
\text { Disparity }\end{array}$ \\
\hline 1. & $\begin{array}{l}\text { Agree or reject mining } \\
\text { massively }\end{array}$ & Position of interest \\
\hline 2. & $\begin{array}{ll}\text { Agree or reject the } \\
\text { existence } \\
\text { unconventional mines }\end{array}$ & Permission \\
\hline 3. & $\begin{array}{l}\text { Agree or reject the } \\
\text { existence of a marine } \\
\text { mining }\end{array}$ & $\begin{array}{l}\text { The interests of } \\
\text { fishermen and marine } \\
\text { biota }\end{array}$ \\
\hline 4. & $\begin{array}{l}\text { Mining by large companies } \\
\text { only or can be done by } \\
\text { anyone }\end{array}$ & $\begin{array}{l}\text { Rights and } \\
\text { accessibility }\end{array}$ \\
\hline 5. & $\begin{array}{l}\text { Activists who support and } \\
\text { reject mining }\end{array}$ & $\begin{array}{l}\text { Orientation } \\
\text { interests }\end{array}$ \\
\hline 6. & $\begin{array}{l}\text { Part of PT. Timah, tbk or } \\
\text { outside of PT. Timah, tbk }\end{array}$ & $\begin{array}{ll}\text { Organization and } & \text { and } \\
\text { production chain } & \end{array}$ \\
\hline 7. & $\begin{array}{l}\text { The interests of the central } \\
\text { government or local } \\
\text { government }\end{array}$ & $\begin{array}{l}\text { Profit and impact } \\
\text { sharing }\end{array}$ \\
\hline 8. & $\begin{array}{l}\text { Directly related to tin } \\
\text { mining or unaffected }\end{array}$ & Impact of mining \\
\hline
\end{tabular}




\begin{tabular}{|l|l|l|}
\hline 9. & $\begin{array}{l}\text { The attitude that the mine is } \\
\text { environmentally damaging } \\
\text { or non-destructive }\end{array}$ & Ideological position \\
\hline 10. & $\begin{array}{l}\text { The attitude that tin mining } \\
\text { is enjoyed or stopped }\end{array}$ & Policy design \\
\hline
\end{tabular}

Based on the table above, it can be seen that in general there appears to be a society divided by several interests which are mutually confrontational to each other. This cleavage is also caused by the dimension of disparity that distinguishes these two things.

\subsection{Focus on Advocacy}

Based on the results of interviews in the field, it was found the fact that the focus of almost all advocacy was regarding the refusal of tin mining activities. The environmental activists interviewed stated that the community and community groups assisted generally had problems with the refusal of tin mining, both those carried out by companies and by unorganized miners through a company.

Activists consider that the community must be supported in the process of rejecting tin mining activities. Assistance is carried out and generally departs from a case that sticks out. Jookie, Gapababel activist said:

\begin{abstract}
" We advocate for the rejection of the community in Pering and in the Belitung sea, both of which are assistance to the community to reject the planned entry of mining vessels in the Belitung Sea". ".
\end{abstract}

Suro, one of the activists in anti-tin mining in East Belitung also said that the rejection he had accompanied was related to the rejection of mining in the Manggar River Watershed and the Oliper Belitung marine mine. Both of them involve the rejection of the mine voiced by the community. Meanwhile, Koko, who is the Legislative Member of the East Belitung Region, also said that the case he had accompanied was a case of refusing tin mining in the watershed.

If this is observed, advocacy is generally carried out because of the issue sticking out about people's refusal. The activities enter and provide reinforcement to groups who refuse. They generally help to put pressure and lobby and negotiate with miners. If we pay attention in general they not only face the miners directly, but also assistance to reject mining companies. This means that advocacy does not look at who the opponent will be rejected, insofar as there are cases of tin mining that raise their resistance, then they will enter and conduct assistance..

\subsection{Depressed Pressure Groups}

LSM/ Non-governmental organizations (NGO) that focus on environmental advocacy can basically be grouped as a pressure group. As a pressure group, environmental advocates will actively move to provide assistance which aims to fight against the marginalization of community rights. As a pressure group, environmental advocates will usually conduct lobbying, negotiations, discussions, and demonstrations to emphasize opponents. The opponents in this case usually are entrepreneurs and financiers, the apparatus used to protect in the name of legality, and / or other social groups of people whose positions are at odds with these pressure groups.

Uniquely, in the case of environmental advocacy, pressure groups are often in a depressed position. The fact that in every advocacy effort carried out they are always faced with pressure from investors to be unavoidable. As told by Fahrizan, one of the activists who said that he had been threatened with death. As for Suro from PKPLH (NGO), he also claimed to have received threats from paid individuals from business groups..

Different things were said by Koko, one of the politicians who persevered in assisting anti-mining groups. He said that he often received intimidation from the mining groups who insisted on mining. But according to him, the formal and legal approach is one of the right alternatives, namely by controlling the security forces together. Jookie from Gapababel NGO said that intimidation from paid groups of entrepreneurs is often accepted. Usually in these conditions they resort to resistance using online media and social media. This method, according to Jookie, is effective in making the cases they accompany more viral and seize the attention of the wider community.

Based on the data and information above, it can be concluded that in the case of environmental advocacy in the tin mining community, the pressure group will face the community or counter-pressure groups that are generally paid for and facilitated by investors. The author calls this a pressure group that is finally depressed. This condition implies that in the case of the environment, investors and activists will go their separate ways to achieve their goals. The financiers themselves will always place instruments outside of formal power to influence decisions, while environmental activists have new tools of struggle, namely social media and online media which are actually quite effective to use.

In some interviews, the authors were informed that almost all environmental activists use social media and mass media to help support their cause. Social media is widely linked, while online media is disseminated through link posting. This is taken to utilize public attention in more collective environmental assistance so that support can be increasingly widespread.

\subsection{Dilemma of Apathy}

One of the reasons why non environmentally friendly mining still occurred with its destruction is that it tends to be the people's apathy in protesting, both directly and indirectly. Actually this can be reflected in the context of the people of Bangka and Belitung who tend to respond to different tin mining. In Bangka, tin mining tends to experience rejection only in a small part of the region [16], while in Belitung it tends to experience broad and collective rejection so that tin mining in Belitung is relatively not as much on Bangka Island [17, 18]. Although there are other logical explanations regarding the development of Belitung tourism which is predicted to be disrupted if mining is allowed to operate, the fact is that 
in a community that is highly resistant tin mining that is not environmentally friendly can be resisted..

Almost all the informants interviewed by the researchers said that the community did tend to be apathetic towards the refusal of tin mining. Although the conditions in Belitung are relatively slightly different from those in Bangka, the informants said that people tend not to bother mining except those who are directly affected, such as fishing communities and residents in coastal areas. Even in the Ibrahim study $[19,20]$ showed that not all fishermen and coastal areas refused tin mining, many of them also received compensation in various forms from tin mining companies..

Jookie, one of the informants in the interview said that actually there are also many who want to participate in the environmental advocacy process that is downstream of the mine refusal, but they are afraid because of intimidation from certain groups. The same thing was recognized by Fahrizan and Koko. Both of them also admitted that there was a tendency for the community not only to be apathetic, but also pragmatic. Pragmatic because as long as they do not feel directly affected they will not feel obliged to be involved. This confirms the results of Ibrahim's study that there is a tendency for pragmatic society to depend on people's income. In an opportunity to interview one of the village administrators in Rebo, Bangka, he said that residents in one of their hamlets were thinking of accepting marine mines because they began to think about enjoying the compensation of the company rather than as long as they only received the damage to their environment.

Thus, it can be read that community apathy in mining advocacy will contribute to the ability of investors to penetrate. This apathy will be sustained by pragmatism when the community starts calculating what profits they get from the mine even though they do not mine directly. Conversely, resistance will strengthen if the community will be participatory and automatically reduce the courage of investors to conduct tin exploitation.

\section{Conclusion}

This research explores how the environmental advocacy dilemma in the tin mining community in Bangka Belitung. Some of the findings in this study include (1) at least ten dimensions that divide local communities into two different conditions, namely attitudes towards the existence of massive mining, attitudes towards the existence of unconventional mines, attitudes towards the existence of marine mines, attitudes on who should conduct tin mining, activist attitudes on mining, attitudes towards the position relationship with PT. Timah, attitudes towards the position of the central and regional governments, attitudes on the impact of mining on the community, attitudes to environmental damage due to mining, and attitudes to the design of tin mining policies are ideal (2) advocacy generally focuses on refusing unfriendly tin mining environment and high damage, such as in the sea, coastal areas and watershed areas, (3) information is found that advocacy will usually be faced with counter-pressure groups who will fight in various ways to derail the advocacy process, and (4) support from the community is relatively limited due to strong apathy and community pragmatism which tends to increase.

Thanks to Directorate of Higher Education of Ministry of Research, Technology, and Higher Education for supporting this research by National Competitive Research Grant 2017-2019.

\section{References}

[1] A. Supriadi, Price Formation Analysis in Indonesia and World Tin Exchanges, Energy and Mineral Resources Data and Information Technology Center, Ministry of Energy and Mineral Resources, Jakarta, (2016)

[2] M. Batubara, Irony of Tin Mining in Babel, was delivered in the University of Bangka Belitung Focus Group Discussion June 25, (2009)

[3] B. Yunianto, 2009. Study of the Problems of Tin Mining in the Bangka Belitung Islands Province as Input of National Defense Policy, Journal of Mineral and Coal Technology Vol. 5, No. 3, July, (2009)

[4] J.F. Carlin, Tin in the US Geological Survey Minerals Yearbook, (2003)

[5] BPS (Badan Pusat Statistik) Provinsi Kepulauan Bangka Belitung, Region Statisitc of Bangka Belitung Islands Province, Year 2018, (2018)

[6] M.F. Heidhues, Bangka Tin and Mentok Pepper, Chinese People Role in 18th to 20th Century Bangka Island Development, Jakarta, Yayasan Nabil, (2008)

[7] J. Susilo, S. Maemunah, Three Ages Serving the World, Portrait of Tin Mining Bangka Belitung, Mining Advocacy Network (JATAM), Jakarta (2009)

[8] S. Sujitno, Impact of Indonesia's Presence of Tin throughout History, Cempaka Publishing, Jakarta (2015)

[9] E. Erman, Journal of Indonesian Society, Actors, Access and Environmental Politics in Bangka Tin Mining, XXVI Edition, No. 2, pp. 71-101 (2010)

[10]D. Haryadi, Illegal Tin Mining (Life Time Problem?), In After 14 years (The Journey Note of Bangka Belitung Islands Province), Yogyakarta, Imperium, (2014)

[11]R.R. Irawan, et.al., Strategic Model of Tin Mining Industry in Indonesia (Case Study of Bangka Belitung Province), International Journal of Business and Management Review, Vol. 2, No. 3, pp. 48-58, (2014)

[12] Ibrahim, et.al., PEOPLE : International Journal of Social Sciences, From Charm to Sorrow (The Dark Portrait of Tin Mining in Bangka Belitung, Indonesia), Vol. 4, Issue 1, pp. 360-382 (2018)

[13] R.M. Siringoringo, T. A. Hadi,. The Condition of Coral Reefs in West Bangka Water dalam Journal Mar. Res. Indonesia Vol. 39, No. 2, pp. 63-71, (2014) 
[14] D. Haryadi, Faktor Kriminogen Ilegal Mining Timah di Bangka Belitung dalam Jurnal Masalah-Masalah Hukum, Jilid 44, No. 1, pp. 52-58 (2015)

[15] Rendy, Women in Politics of Tin Resources: Multiple Problems of Human Rights under the Curse Shadows of Natural Resources - Tin Mining in Bangka Belitung Islands, Proceedings of The 7th Annual International Conference (AIC) Syiah Kuala University and The 6th International Conference on Multidisciplinary Research (ICMR) in conjunction with the International Conference on Social Science 2017, October 18-20, 2017, Banda Aceh, Indonesia, (2018)

[16]S. Pratama, The Politial Economy Dimension Towards Conflict of Mining Governance (Case Study: Bangka Belitung Governoor's Regulation About The Moratorium Of PT Timah, Tbk Offshore Tin Mining 2016), Jurnal Wacana Politik, Vol. 3, No. 1, Maret, pp. $40-53,(2018)$

[17] Ibrahim, D. Haryadi, N. Wahyudin, Ekonomi Politik Sumber Daya Timah (Kronik Bangka Belitung), Yogyakarta, Imperium, (2018)

[18] Ibrahim, D. Haryadi, N. Wahyudin, Local Fisherman Resistence in Kelapa Kampit Coastal AreaToward Offshore Mining Activities, Web of Conferences, Vol. 47. pp. 1-20 (2018)

[19] Ibrahim, D. Haryadi, N. Wahyudin, Make Peace With the Damaged Coast (The Experience of Mentok Coastal Community in Adapting the Offshore Tin Mining), Web of Conferences, Vol. 47, pp. 1-10, (2018)

[20] Ibrahim, D. Haryadi, N. Wahyudin, Between Fishing, Mining, and Suction Vessel: The Compromise of Teluk Limau People, West Bangka, On Tin Mining Aggresion, PEOPLE: International Journal of Social Sciences, Vol. 5 Issue 1, pp.178 - 185, (2019) 